\title{
Impact of Market Learning on Management Innovation: Mediating role of Knowledge Integration
}

\author{
Saman Fatima ${ }^{1}$, Roshan Luqman*2 \\ 1,2 Institute of Banking and Finance, Bahauddin Zakariya University, Multan, \\ Pakistan. \\ * Corresponding author: roshan.luqman@yahoo.com
}

\author{
Article History \\ Received 2020-07-01 \\ Revised 2020-07-26 \\ Accepted 2020-07-29 \\ Published 2020-08-02
}

\section{Keywords \\ Management Innovation \\ Market Learning \\ Knowledge Integration}

\section{How to cite?}

Fatima, S., \& Luqman, R. (2020).

Impact of Market Learning on

Management Innovation. Mediating role of

Knowledge Integration. SEISENSE

Journal of Management, 3(5), 1-12. doi:

$10.33215 /$ sjom.v3i5.404

\section{Abstract}

Purpose- The article aims to study and explore the effect of market learning on management innovation along with exploring the role of knowledge integration as a mediator in the hospitality industry of Pakistan.

Design/Methodology- The data comprised 215 respondents from the hospitality industry, and it was gathered through a questionnaire containing 22 items, including four demographical items. The gathered data was utilized to validate our model empirically through statistical tests.

Findings- Research findings reveal that management innovation is driven by market learning, and significant relationships exist between market learning, knowledge integration, and management innovation. The mediating role of knowledge integration also exists significantly between management innovation and market learning.

Novelty - Knowledge integration about management innovation and market learning is a novel contribution, and findings suggest that its effect on this model is significant.

Practical Implications- Successful organizations include knowledge integration and management innovation as a critical part of their culture as these variables boost the firm's productivity and employee participation, and both are found to be driven by market learning. The managers can make an effort to enhance market learning and improve the firm's overall performance. 


\section{Introduction}

Literature that follows market-driven organizational patterns has specifically introduced market learning as a significant provenance of innovation and solid execution (Day, 1994). According to the 1960s market pull approach to innovation, firms should examine the scope of new opportunities that are supposed to satisfy their customer base to be active innovators (Levitt, 2004). Arguments claim that Initiating point for innovation is through assembling and circulation of marketplace knowledge to form an innovative idea (Foxall \& Fawn, 1992). To enhance the affectation and success of innovation, it is likely that the apprehension of market choices lessens the level of the discrepancy of the latest products with the requirements of the customer (Cooper \& Kleinschmidt, 1987).

Using formal procedures and structures that allow capturing the market and other knowledge while integrating it in different functional units of an organization is defined as knowledge integration (Olson, Walker Jr, \& Ruekert, 1995). The literature has identified different roots of knowledge integration. Out of these, teamwork is of the utmost gravity. Knowledge exchange between specialists resulting in improved solutions and new idea development is facilitated by teamwork (Becker \& Zirpoli, 2003). Sharing of knowledge is not the only aspect of knowledge integration; instead of generating new knowledge is significant as people conjoin information they hold (Okhuysen \& Eisenhardt, 2002). In light of dynamic capabilities view (Eisenhardt \& Martin, 2000), we can conceptualize that attaining new knowledge through internal or external means leads to innovative service firms where this knowledge adds up to the existing one. In this intensifying competitive business environment, firms are required to focus on their management model innovation to sustain competitive advantage. Birkinshaw, Hamel, and Mol (2008) indicate that the primary reason for the success of P\&G, DuPont, and GE is their innovation in their management models. Management Innovation is defined as the development and implementation of a management practice, structure, technique or process (Birkinshaw et al., 2008). Management Innovation helps to maintain a long-lasting competitive edge that becomes difficult to copy (Pisano \& Teece, 2007). Management innovation significantly affects the organization's performance by gaining a competitive advantage. Emotional exhaustion of employees is caused by doing the same job task in the same manner, and emotional exhaustion has a direct and positive relationship with counterproductive work behavior (Luqman, Fatima, Ahmed, Khalid, \& Bhatti, 2020). Therefore, management innovation is vital to boost employee performance in the organizations. Management practices and structures have economical as well as social influence on the firm. For firms to attain a competitive edge, management innovation has been argued to be the dominant and feasible origin (Hamel, 2006). It is becoming a problem of value as firms search for ways and means to enhance their productivity and competitiveness in the global market.

Previous studies mostly focused on the adoption of this process and a successful transition after the adoption. However, new technologies are often not adopted in their current form but adapted by the firms while in the process (Rogers, 2003). Literature has focused chiefly on technological innovation; however, the horizon of management innovation remains unexplored. Despite this, with the availability of resources, firms are investing more towards management practices to gain a competitive edge (Bromiley \& Rau, 2014). Prevailing management practices, processes, and diaphragms are being revised by firms to encourage firm performance. The relationship between management innovation and market learning has been part of literature in the past. Still, the incorporation of knowledge integration as a mediator is a new contribution to literature. This research aims to fill the gap of knowledge integration as a mediator between management innovation and market learning.

The significance of this study is that it can help many firms to reinvent their management models to be successful in today's competitive world. Large scale organizations have specific formal procedures to implement new ways of management, while small scale firms can quickly implement new management ways, which are 
crucial for their success. Google has an entirely different model of management in which employees have freedom in their work, and they focus on innovation. Mol and Birkinshaw (2009) described that management knowledge could be acquired through productive market learning, and it will help to break the inertia in the management innovation process. Hence, the companies that focus on market learning are more likely able to reinvent their management models. Previous studies show that the innovation potential of a firm can be increased by collecting knowledge from different stakeholders (Slotegraaf, 2012), by spreading a market/learning-oriented environment (Marinova, 2004), and promoting knowledge sharing behavior within the firm (Arnett \& Wittmann, 2014). Therefore, market learning and knowledge integration are crucial in the management innovation process of a firm.

This study aims to explore the relationship between Market Learning, Management Innovation, and Knowledge Integration. The first objective of this paper is to study the relationship between Market Learning and Management Innovation. The second objective of this paper is to study the relationship between Market Learning and Knowledge Integration. The third objective includes the study of the relationship between Knowledge Integration and Management Innovation. The fourth objective is to explore the mediating effect of Knowledge Integration between Market Learning and Management Innovation. This research paper contains distinct objectives as we have Management Innovation as a dependent variable; we are focusing on addressing innovation in the field of management. Management Innovation is essential because the companies which have innovated their management models like HCL Technologies and W. L. Gore have experienced so much success. HCL Technologies is a company that follows a 360 -feedback management practice in which the subordinates are required to give feedback about their leaders. W. L. Gore is a company, and they have management in which job titles are not given to the employees of the organization.

In contrast, employees have a set of responsibilities. These disruptive management models are the key features behind the success of these organizations. In this way, innovation in management practices enhances employee participation and productivity, and it leads to the success of the organization.

The rest of this research paper is organized in the following manner. The Literature review section contains the relevant arguments on Management Innovation, Market Learning and Knowledge Integration, and all fourhypothesis defining the relationship between these variables. The methodology section entails the details of the research method and the demographical details of the respondents in this paper. Next, the analysis section conceptualizes the responses of this study and relationships among variables. The findings section represents the study findings and the significance of these variables. Lastly, the paper contains the limitations of this study with directions for future research.

\section{Literature Review}

\section{Market Learning and Management Innovation}

Market learning refers to the new ideas and knowledge acquired from outside the boundaries of the company (Wang \& Yang, 2018). Weerawardena (2003) defines market learning as it includes the knowledge about customers' needs and strategies of competitors. The literature of management innovation requires equal attention from the researchers concerning technological innovation. Bromiley and Rau (2014) state that management practices in firms have a high level of investment to achieve and maintain competitive advantage as the resources are easily accessible. In other words, Management innovation is defined as using new management practices or ideas in an organization (Wei, Song, \& Xie, 2019). Therefore, the concept of MI has high significance in order to outperform the competitors and develop good reputation.

Management innovation aims to achieve a better managerial system in the organization by considering the external sources of knowledge. Managerial systems that are not fit for the organization must be addressed, and 
new practices should be implemented for a better routine system (Lin, Murphree, \& Li, 2017; Volberda, Van Den Bosch, \& Mihalache, 2014). The management capability of a company can be judged by external stakeholders based on management innovation (Wei et al., 2019). Therefore, management innovation helps build a sharp firm image for the external stakeholders, which exhibits excellent management capability of the firm. The organization which focuses on innovation, develop and polish market learning capabilities can gain and sustain competitive advantage and are more valuable for its customers (Weerawardena, 2003). This argument gives us insight that market learning is crucial for the process of MI. Khosravi, Newton, and Rezvani (2019) states that MI has a definite relation to organizational learning. Carboni and Russu (2018) define that market knowledge is crucial to break the inertia and innovate the management of the organization. Hence, market learning has a positive impact on management innovation, and it creates opportunities to identify and implement the right management practices in the organization.

Hypothesis 1: Market learning has a positive relationship with management innovation.

\section{Market Learning and Knowledge Integration}

The knowledge and information gathered by the company from the outside of its boundaries are defined as market learning (Kim \& Atuahene-Gima, 2010). Market knowledge is crucial in creating opportunities for management innovation, and it enables firms to pursue new management practices and approaches. Market learning is highly significant for any organization that is trying to gain a competitive advantage. Wilden and Gudergan (2015) provide evidence that to develop the firm's capabilities, including technological and nontechnological, the firm must have to gather market information effectively and integrate the knowledge that is valuable for the firm. Hence, learning from the market and integration of that knowledge is significantly corelated and gives a clear insight into the development of the organizational capabilities.

The innovation process of a firm can be improved by combining the existing and newly acquired market knowledge, and knowledge integration can be done effectively when there are proper integration and operational mechanisms (Azadegan, Dooley, Carter, \& Carter, 2008; Berggren, Bergek, Bengtsson, Söderlund, \& Hobday, 2011; Lane, Koka, \& Pathak, 2006; Martín-de Castro, López-Sáez, Delgado-Verde, \& Koch, 2011). Existing knowledge and new market knowledge is equally essential to develop the best management practices in the organization that are beneficial for the organization and attractive for the external stakeholders. Knowledge integration enables the firm to share valuable information and make it widely available within the organization. It is evident that entrepreneurial organizations focus on market learning and actively implement knowledge integration in the technological and managerial practices that create value for the organization (Weerawardena, 2003). Therefore, market learning is significant to obtain a competitive advantage by integrating the acquired knowledge within an organization for better decision making about different areas of management systems.

Hypothesis 2: Market learning has a positive relation to knowledge integration.

\section{Knowledge Integration and Management Innovation}

The propensity to fuse knowledge inside and outside the organizational parameters is known as knowledge integration. Companies use knowledge as a central resource to preserve an enduring competitive edge (Maravilhas \& Martins, 2019). Effectiveness of knowledge integration is influenced by the quality of knowledge gained. To integrate knowledge is a procedure to store and evolve knowledge (Ahmad, Bosua, \& Scheepers, 2014). Knowledge integration may help to steer a company's production procedures (Furlan, Vinelli, \& Dal Pont, 2011). The project performance levels of different companies can be justified through integration ability. Internally accessible knowledge demands a shared viewpoint about future challenges or hurdles to allow the formulation of a new remedy by combining existing knowledge, according to Okhuysen and Eisenhardt (2002). 
Social Interactions among individuals using internally available communication medium allows a shared perspective formulation. To pass on specific inside information, these inter-unit connections are fundamental (Tsai, 2001). Transmission of knowledge permits its reuse and its reconciliation, which is a major aspect of management innovation (Majchrzak, Cooper, \& Neece, 2004).

The company's integration ability proves to be a priceless resource for employees with diverse kinds of knowledge. Internal communication is the central part of knowledge integration, as it can become multiplex in more prominent firms, hampering knowledge integration and its impact that correlates, in this scenario, management innovation (Mol \& Birkinshaw, 2009; Walker, Damanpour, \& Devece, 2011). Elevated levels of trust and collaboration are induced by higher networking in employees. Managers would use these results to incorporate managerial innovations at a higher level, improved understanding of business, and gain more knowledge to nurture new concepts (Jansen, Van Den Bosch, \& Volberda, 2006). The extent of integration is mainly recognized by the motivation and skillset of employees (Collins \& Smith, 2006). In knowledge integration, a shared vision of the firm is created in the organizational context, which allows the transfer and processing of inside and outside knowledge (Cummings, 2004). Thus, integration promotes the transmission of versatile data into a new format of integrated and original knowledge, supporting the innovation process (Salazar, Lant, Fiore, \& Salas, 2012). The essence of this discussion helps us to formulate the hypothesis:

Hypothesis 3: Knowledge Integration is directly related to Management Innovation.

\section{Market Learning, Knowledge Integration and Management Innovation}

Firms must know the pre-requisites before entering a new market, handling cross-cultural scenarios, and setting a fresh mindset inside the organization (Anderson, Boocock, \& Graham, 2001). Inadequate knowledge of the market's businesses and institutes could result in mounting unrecognized costs and risks, which hinders the firm's expansion (Eriksson, Johanson, Majkgård, \& Sharma, 2000). Market learning focuses on the intuition and mental patterns of market behaviors, expectations related to firms' market, customer needs, competitor proficiency, market reactions to firm operations, and trends of existing market opportunities. The ability to adapt according to market type is necessary alongside precise market knowledge, according to Eriksson et al. (2000). Thus, market learning is the desired phenomenon at the firm level to enable promotion in multiple business conditions. Advancement of this process is suggested through the use of knowledge management systems, particularly knowledge integration. It allows proper positioning and acculturation of present knowledge for the formation of up-to-date knowledge. Members become more able to understand the consequences lead by their actions as part of the cause and effect process (Zollo \& Winter, 2002). Having this system makes it easier to recognize customer needs and pinpoint market opportunities (Lu, Zhou, Bruton, \& Li, 2010). At this point, assimilated procedures are interpreted into managerial expertise to cater to the needs of the firm's customer (Hamel \& Prahalad, 1996). This knowledge integration process comprises three steps mainly to capture, interpret, and use the acquired knowledge inside the organization (Zahra, Ireland, \& Hitt, 2000). We capture to allow better availability of information to firm members through documentation and trade-off. Interpretation plays its role to review and assess new information (Von Hippel \& Tyre, 1995). In knowledge, an integration firm creates a standard in terms of the organization promoting external and internal knowledge transfer and processing (Cummings, 2004). Thus, integration promotes the transmission of versatile data into a new format of integrated and original knowledge, supporting the innovation process (Salazar et al., 2012). So, knowledge integration allows the flow of diversified information into the current format of integrated and authentic knowledge, assisting the innovation process. This argument leads us to the hypothesis:

Hypothesis 4: Knowledge Integration is mediating the positive relation between Market Learning and Management Innovation. 


\section{Theoretical Framework}

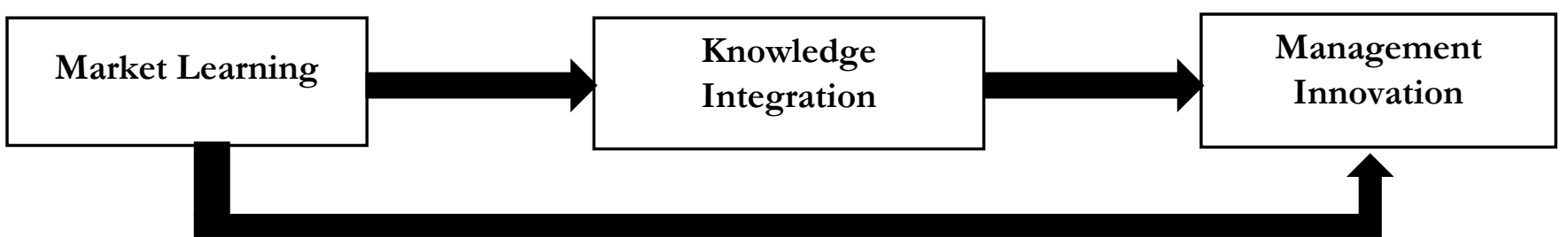

\section{Figure 1 - Conceptual Framework}

The model displayed in figure 1 is the theoretical framework of this study. The relationship between management innovation and market learning is positive because the market knowledge enhances the capability of a firm to induce innovation in its management practices. Market learning is related to knowledge integration as the market knowledge must be shared within the organization to keep everyone aware of the necessary information about the market conditions. The extent to which the knowledge is integrated within a firm determines the ability to innovate its management practices. In this way, knowledge integration takes forward the indirect effect, and it mediates the relationship between market learning and management innovation.

\section{Methodology}

This study uses the quantitative research method to explore the outcomes. Our survey helped us develop the findings in a specific time constraint as a result of the cross-sectional method being adopted. The hospitality sector of Pakistan was selected to be studied, giving us 215 responses through specified criteria. The Snowball sampling technique is used to gather data through a survey questionnaire as this research has been conducted during the COVID-19 pandemic. This research solely focused on the hospitality sector because of its growing scope in Pakistan. Investigation, purpose, and moral affairs were made clear from the start. The mechanism holds two sections. Firstly, the demographics of the respondent. Secondly, a complete study of variables. Our sample withholds a male percentage of 73.5 percent and 26.5 percent of females.

The prominent age groups in our responses were from 18-35 years. Five items Likert scale was used where 1 represents SD strongly disagree while five is for strongly agree. All the variables had a varied number of items in the questionnaire. Market Learning comprises nine items adaptation from Kim and Atuahene-Gima (2010), whereas Management Innovation holds four items adapted from Yang, Li, Jiang, and Zhao (2020). Similarly, Knowledge Integration resides with five items adjusted from Grant (1996) in the survey. Primary sources were inherited to collect data where employees of hotels and restaurants filled the surveys. Many statistical tests, such as KMO Measure of Sampling Adequacy, Reliability Analysis, and Regression, were applied to examine the gathered data.

\section{Analysis and Results}

The number of respondents in our data is 215 , and data is gathered from the employees of the hospitality industry. In our data, 73.5 percent was the proportion of males, and 26.5 percent was the proportion of females. The data constituted of 66.5 percent of 21 to 30 years, 27 percent of 31 to 40 years, 5.6 percent of 41 to 50 years and 0.9 percent of 51 or above years of age. 2.8 percent of respondents have Intermediate degrees, 28.8 percent of respondents have a graduation degree, 66 percent of respondents have a Masters MS/M Phil degree, and 1.4 percent of respondents have other degrees. The income group of 20,000 to 34,999 PKR is 32.6 percent, 35,000 to 49,999 PKR is 25.1 percent, 50,000 to 64,999 PKR is 26 percent and 65,000 PKR or above is 16.3 percent.

Factor analysis has given the KMO value of 0.951 , which manifests that our sample size is highly adequate, and the p-value is less than 0.001 , as shown in table 1 . The items loaded of each variable in the pattern matrix is 
represented in table 2. The reliability analysis manifests the value of Cronbach's Alpha is 0.962 , which higher than the degree of 0.65 , and it shows that the items in our research are internally consistent, as represented in table 3. Correlation analysis shows that the correlation of the variables is significant at the level of 0.01 , as manifested in table 4.

Table 1 - KMO and Bartlett's Test

\begin{tabular}{lrr}
\hline Kaiser-Meyer-Olkin Measure of Sampling Adequacy. & $\mathbf{9 5 1}$ \\
\hline Bartlett's Test of Sphericity & Approx. Chi-Square & 3549.409 \\
& df & 153 \\
& Sig. & .000 \\
\hline
\end{tabular}

Table 2 - Factor Loadings

Codes Statements Loadings

\section{Management Innovation}

MI1 We regularly implement a new routine for finishing the task.

MI2 We regularly implement new ways to enhance the degree of employee satisfying and .865 efficiency of work procedures.

MI3 We regularly implement new processes and systems.

MI4 We regularly implement a new way to achieve the target.

\section{Market Learning}

ML5 Used market information and ideas involving experimentation and high risk. $\quad .895$

ML4 Used market information and ideas with no identifiable market needs $\quad .876$

ML8 Used market information and ideas that may contribute to the firm's existing product $\quad .872$

ML3 Used novel product/market ideas that may not necessarily be successful in the current $\quad .859$

ML2 Used market information from lead users that forces project team members to learn $\quad .831$ about new things in our markets.

ML7 Emphasized using proven ideas for solutions to marketing problems. 826

ML9 Undertook activities that help to utilize or integrate the firm's current market .817

ML6 Used new ideas that are consistent with our current product- market experiences. $\quad .791$

ML1 Used market information that takes the firm beyond its current product market $\quad .783$ experiences.

\section{Knowledge Integration}

KI3 There were generally accepted behavior patterns that governed actions when rules and procedures did not.

KI2 The firm had production activities divided into independent phases and organized sequentially.

KI1 The rules/policies of the firm enabled the coordination of activities and information flows.

KI4 The organization resolved uncertainty through conflict resolution and decision-making groups.

KI5 The rules, sequences, behaviors patterns, and groups enabled useful sharing knowledge among members of the firm, avoiding unnecessary transfers. 
Table 3 - Reliability Analysis

\begin{tabular}{lcc}
\hline Variables & Number of items & Reliability $(\boldsymbol{\alpha})$ \\
\hline MI, ML, and KI & Total $=18$ & .962 \\
Management Innovation & 4 & .909 \\
Market Learning & 9 & .958 \\
Knowledge Integration & 5 & .917 \\
\hline
\end{tabular}

Table 4 - Correlation Analysis

\begin{tabular}{lccc}
\hline Correlation & ML & KI & MI \\
\hline ML & 1 & $.695^{* *}$ & $.674^{* *}$ \\
KI & $.695^{* *}$ & 1 & $.653^{* *}$ \\
MI & $.674^{* *}$ & $.653^{* *}$ & 1 \\
\hline
\end{tabular}

Note: **Correlation significant at 0.01 level.

\section{Hypothesis Testing}

\section{Hypothesis 1: Market Learning has a positive relation with Management Innovation.}

The assumed hypothesis is supported as the p-value is 0.000 , which is significantly smaller than 0.05 degree, as displayed in table 5. The Standardized Coefficients $\beta$ is 0.674 , which exhibits that increase in 1 unit of Market Learning results in an increase in 0.674 units of Management Innovation. The $\mathrm{R}$ square value is 0.454 , which manifests that Market Learning causes a 45.4 percent change in Management Innovation. 54.6 percent change in Management Innovation is still undetermined, and the t-value is 13.321. The result exhibits that Market Learning has a positive and significant relationship with MI.

Table 5 - Market learning relation and Management Innovation

\begin{tabular}{lccccc}
\hline Hypothesis & $\beta$-Coefficient & R-square & t-value & p-value & Result \\
\hline 1. ML \& MI & .674 & .454 & 13.321 & .000 & Supported \\
\hline
\end{tabular}

\section{Hypothesis 2: Market learning has a positive relation to knowledge integration.}

The assumed hypothesis is supported as the p-value is 0.000 , which is significantly lower than 0.05 degree, as manifested in table 6. The Standardized Coefficients $\beta$ is 0.695 , which manifests that an increase in 1 unit of Market Learning results in an increase in 0.695 units of Knowledge Integration. The $\mathrm{R}$ square value is 0.482 , which manifests that an overall 48.2 percent change in Knowledge Integration is caused by Market Learning. 51.8 percent change in Knowledge Integration is still undetermined, and the t-value is 14.088 . The result exhibits that Market Learning has a positive and significant relationship with KI.

Table 6 - Market learning relation and Knowledge Integration

\begin{tabular}{lccccc}
\hline Hypothesis & $\beta$-Coefficient & R-square & t-value & p-value & Result \\
\hline 2. ML \& KI & .695 & .482 & 14.088 & .000 & Supported \\
\hline
\end{tabular}

\section{Hypothesis 3: Knowledge Integration is directly related to Management Innovation.}

The assumed hypothesis is supported as the p-value is 0.000 , which is significantly smaller than 0.05 degree, as exhibited in table 7. The Standardized Coefficients $\beta$ is 0.653 , which manifests that an increase in 1 unit of Knowledge Integration increases 0.653 units of Management Innovation. The R square value is 0.427 , which manifests that Knowledge Integration causes 42.7 percent change in Management Innovation. 57.3 percent change in Management Innovation is still undetermined, and the $\mathrm{t}$-value is 12.594. The result exhibits that Knowledge Integration has a positive and significant relationship with MI. 
Table 7 - Knowledge Integration and Management Innovation

\begin{tabular}{lccccc}
\hline Hypothesis & $\boldsymbol{\beta}$-Coefficient & R-square & t-value & p-value & Result \\
\hline 3. KI \& MI & .653 & .427 & 12.594 & .000 & Supported \\
\hline
\end{tabular}

\section{Hypothesis 4: Knowledge Integration is mediating positive relation between Market Learning and Management Innovation.}

The assumed hypothesis is supported as an indirect effect between ML and MI exists through Knowledge Integration; it is analyzed through Preacher and Hayes Analysis for mediation using model 4. The finding manifests that the indirect effect is .2367 , which exhibits knowledge integration is taking ahead 23.67 percent impact of Market Learning to Management Innovation as manifested in table 8. The Upper Limit Confidence interval and Lower Limit Confidence interval do not contain 0 , which means the mediation is intense. This suggests that the mediation effect exists, and the results are significant statistically.

Table 8 - Mediation Analysis

\begin{tabular}{lccccc}
\hline Hypothesis & Effect & p-value & LLCI & ULCI & Result \\
\hline 4. KI, ML \& MI & & & & & \\
Total Effect & .6424 & .000 & .5473 & .7374 & \\
Direct Effect & .4057 & .000 & .2816 & .5298 & \\
Indirect Effect & .2367 & .000 & .1062 & .3714 & Supported
\end{tabular}

\section{Discussion}

Past research also proves that Innovation process of a firm can be improved by combining the existing and newly acquired market knowledge and knowledge integration can be done effectively when there are proper integration and operational mechanisms (Azadegan et al., 2008; Berggren et al., 2011; Lane et al., 2006; Martínde Castro et al., 2011). The disruptive management models of successful organizations like HCL Technologies and Google have transpired the concept of management innovation in the modern dynamic business environment. This study speculates the role of market learning in the innovation of management practices of the organization. Market learning allows the inward flow of outside information and knowledge within the parameters of the organization (Kim \& Atuahene-Gima, 2010). Market learning as a source of extrinsic knowledge plays a vital role in stimulating the management innovation process, creating possibilities for firms to discover a broader range of management approaches and methods. Thus, Market Learning and Management Innovation are directly related variables. Entrepreneurial organizations focus on market learning and actively implement knowledge integration in the technological and managerial practices that create value for the organization (Weerawardena, 2003). Therefore, Knowledge Integration enhances the process of Market Learning. In knowledge integration, a shared vision of the firm is created in the organizational context, which allows the transfer and processing of inside and outside knowledge (Cummings, 2004). This integration promotes the transmission of versatile data into a new format of integrated and original knowledge, supporting the innovation process (Salazar et al., 2012). Hence, we can say that knowledge integration and management innovation have a positive relationship. This discussion also supports the mediating role of knowledge integration between market learning and management innovation. Finally, we are able to say that market learning magnifies the impact of management innovation practices with complementary role of knowledge integration.

\section{Conclusion}

The results of this study are consistent with the assumed hypotheses. The findings will create value by combining market learning, management innovation, and knowledge integration. The incorporation of knowledge integration as a mediator is a new contribution to the existing literature as knowledge integration 
contemplates market learning to augment the extent of management innovation. Sustainability of competitive advantage is crucial for the success of a firm, and management innovation accelerates this process. In the hospitality sector, managers tend to follow more unconventional approaches when organizational culture allows speculating the market changes and promotes the incorporation of knowledge among employees and managers at different levels. Thus, management style becomes more unorthodox and creates the right mix of practices and procedures evolving according to the firm's requirement. This model could help enhance employee participation, thus lead to a firm's productivity.

\section{Limitations and Further Research}

Every research encompasses a variant set of limitations, giving the idea of the researcher's boundaries. The same is the case with our analysis as it confines us within the scope of a limited topic. Prime limitations are the following:

1. The scope of this paper is bounded within the hospitality industry; hence, future research should induce our findings in other service sectors.

2. Also, it would be fascinating to incorporate the role of emotions as a moderator between knowledge integration and management innovation as emotions have a significant impact on the work behavior of employees (Luqman et al., 2020)

3. As we conducted our research in a developing country, researchers can empirically test this model in developed countries to measure the impact of economic conditions.

Funding: This research received no external funding.

Conflict of Interest: The authors declare no conflict of interest.

\section{References}

Ahmad, A., Bosua, R., \& Scheepers, R. (2014). Protecting organizational competitive advantage: A knowledge leakage perspective. Computers \& Security, 42, 27-39.

Anderson, V., Boocock, G., \& Graham, S. (2001). An investigation into the learning needs of managers in internationalising small and medium-sized enterprises. Journal of Small Business and Enterprise Development, 8(3), 215-232.

Arnett, D. B., \& Wittmann, C. M. (2014). Improving marketing success: The role of tacit knowledge exchange between sales and marketing. Journal of Business Research, 67(3), 324-331.

Azadegan, A., Dooley, K. J., Carter, P. L., \& Carter, J. R. (2008). Supplier innovativeness and the role of interorganizational learning in enhancing manufacturer capabilities. Journal of Supply Chain Management, 44(4), 14-35.

Becker, M. C., \& Zirpoli, F. (2003). Organising new product development: Knowledge hollowing-out and knowledge integration: DRUID, Copenhagen Business School, Department of Industrial Economics and ....

Berggren, C., Bergek, A., Bengtsson, L., Söderlund, J., \& Hobday, M. (2011). Knowledge integration and innovation: Critical challenges facing international technology-based firms: Oxford University Press.

Birkinshaw, J., Hamel, G., \& Mol, M. J. (2008). Management innovation. Academy of management review, 33(4), 825-845.

Bromiley, P., \& Rau, D. (2014). Towards a practice-based view of strategy. Strategic Management Journal, 35(8), 1249-1256. 
Carboni, O. A., \& Russu, P. (2018). Complementarity in product, process, and organizational innovation decisions: Evidence from European firms. R※D Management, 48(2), 210-222.

Collins, C. J., \& Smith, K. G. (2006). Knowledge exchange and combination: The role of human resource practices in the performance of high-technology firms. Academy of management journal, 49(3), 544-560.

Cooper, R. G., \& Kleinschmidt, E. J. (1987). New products: what separates winners from losers? Journal of product innovation management, 4(3), 169-184.

Cummings, J. N. (2004). Work groups, structural diversity, and knowledge sharing in a global organization. Management science, 50(3), 352-364.

Day, G. S. (1994). The capabilities of market-driven organizations. Journal of marketing, 58(4), 37-52.

Eisenhardt, K., \& Martin, J. (2000). Dynamic capabilities: What are they? Strategic Management Journal, 21 (10/11): 1105-1121: October-November.

Eriksson, K., Johanson, J., Majkgård, A., \& Sharma, D. D. (2000). Effect of variation on knowledge accumulation in the internationalization process. International Studies of Management \& Organization, 30(1), 26-44.

Foxall, G. R., \& Fawn, J. R. (1992). An evolutionary model of technological innovation as a strategic management process. Technovation, 12(3), 191-202.

Furlan, A., Vinelli, A., \& Dal Pont, G. (2011). Complementarity and lean manufacturing bundles: an empirical analysis. International Journal of Operations \& Production Management.

Grant, R. M. (1996). Toward a knowledge-based theory of the firm. Strategic Management Journal, 17(S2), 109122.

Hamel, G. (2006). The why, what, and how of management innovation. Harvard business review, 84(2), 72.

Hamel, G., \& Prahalad, C. K. (1996). Competing for the Future: Harvard Business Press.

Jansen, J. J., Van Den Bosch, F. A., \& Volberda, H. W. (2006). Exploratory innovation, exploitative innovation, and performance: Effects of organizational antecedents and environmental moderators. Management science, 52(11), 1661-1674.

Khosravi, P., Newton, C., \& Rezvani, A. (2019). Management innovation: A systematic review and metaanalysis of past decades of research. European Management Journal, 37(6), 694-707.

Kim, N., \& Atuahene-Gima, K. (2010). Using exploratory and exploitative market learning for new product development. Journal of product innovation management, 27(4), 519-536.

Lane, P. J., Koka, B. R., \& Pathak, S. (2006). The reification of absorptive capacity: A critical review and rejuvenation of the construct. Academy of management review, 31(4), 833-863.

Levitt, T. (2004). Marketing myopia. Harvard business review., 82(7/8), 138-149.

Lin, H., Murphree, M., \& Li, S. (2017). Emergence of organizational routines in entrepreneurial ventures. Chinese Management Studies.

Lu, Y., Zhou, L., Bruton, G., \& Li, W. (2010). Capabilities as a mediator linking resources and the international performance of entrepreneurial firms in an emerging economy. Journal of International Business Studies, 41(3), 419-436.

Luqman, R., Fatima, S., Ahmed, S., Khalid, I., \& Bhatti, A. (2020). The Impact of Autocratic Leadership Style on Counterproductive Work Behavior: The Mediating role of Employee Commitment and Moderating role of Emotional Exhaustion. Pollster Journal of Academic Research, 06(01), 22-47.

Majchrzak, A., Cooper, L. P., \& Neece, O. E. (2004). Knowledge reuse for innovation. Management science, 50(2), 174-188.

Maravilhas, S., \& Martins, J. (2019). Strategic knowledge management in a digital environment: Tacit and explicit knowledge in Fab Labs. Journal of Business Research, 94, 353-359.

Marinova, D. (2004). Actualizing innovation effort: the impact of market knowledge diffusion in a dynamic system of competition. Journal of marketing, 68(3), 1-20. 
Martín-de Castro, G., López-Sáez, P., Delgado-Verde, M., \& Koch, A. (2011). Firm-internal knowledge integration and the effects on innovation. Journal of Knowledge Management.

Mol, M. J., \& Birkinshaw, J. (2009). The sources of management innovation: When firms introduce new management practices. Journal of Business Research, 62(12), 1269-1280.

Okhuysen, G. A., \& Eisenhardt, K. M. (2002). Integrating knowledge in groups: How formal interventions enable flexibility. Organization science, 13(4), 370-386.

Olson, E. M., Walker Jr, O. C., \& Ruekert, R. W. (1995). Organizing for effective new product development: The moderating role of product innovativeness. Journal of marketing, 59(1), 48-62.

Pisano, G. P., \& Teece, D. J. (2007). How to capture value from innovation: Shaping intellectual property and industry architecture. California management review, 50(1), 278-296.

Rogers, E. (2003). Diffusion of innovations, 5th edn Tampa. FL: Free Press.[Google Scholar].

Salazar, M. R., Lant, T. K., Fiore, S. M., \& Salas, E. (2012). Facilitating innovation in diverse science teams through integrative capacity. Small Group Research, 43(5), 527-558.

Slotegraaf, R. J. (2012). Keep the door open: Innovating toward a more sustainable future. Journal of product innovation management, 29(3), 349-351.

Tsai, W. (2001). Knowledge transfer in intraorganizational networks: Effects of network position and absorptive capacity on business unit innovation and performance. Academy of management journal, 44(5), 996-1004.

Volberda, H. W., Van Den Bosch, F. A., \& Mihalache, O. R. (2014). Advancing management innovation: Synthesizing processes, levels of analysis, and change agents. Organization Studies, 35(9), 1245-1264.

Von Hippel, E., \& Tyre, M. J. (1995). How learning by doing is done: problem identification in novel process equipment. Research policy, 24(1), 1-12.

Walker, R. M., Damanpour, F., \& Devece, C. A. (2011). Management innovation and organizational performance: The mediating effect of performance management. Journal of Public Administration Research and Theory, 21(2), 367-386.

Wang, L., \& Yang, Y. (2018). Study on the relationship between external Learning and Radical Innovation. Paper presented at the 3rd International Symposium on Asian B\&R Conference on International Business Cooperation (ISBCD 2018).

Weerawardena, J. (2003). Exploring the role of market learning capability in competitive strategy. European journal of marketing.

Wei, Z., Song, X., \& Xie, P. (2019). How does management innovation matter for performance: Efficiency or legitimacy? Chinese Management Studies.

Wilden, R., \& Gudergan, S. P. (2015). The impact of dynamic capabilities on operational marketing and technological capabilities: investigating the role of environmental turbulence. Journal of the Academy of Marketing Science, 43(2), 181-199.

Yang, D., Li, L., Jiang, X., \& Zhao, J. (2020). The fit between market learning and organizational capabilities for management innovation. Industrial Marketing Management, 86, 223-232.

Zahra, S. A., Ireland, R. D., \& Hitt, M. A. (2000). International expansion by new venture firms: International diversity, mode of market entry, technological learning, and performance. Academy of management journal, 43(5), 925-950.

Zollo, M., \& Winter, S. G. (2002). Deliberate learning and the evolution of dynamic capabilities. Organization science, 13(3), 339-351. 